\title{
Analysis of Metacognitive Awareness of Primary and Secondary School Students in Terms of Some Variables
}

\author{
Selva Bakkaloglu ${ }^{1}$ \\ ${ }^{1}$ Education Faculty, Karamanoglu Mehmetbey University, Karaman, Turkey \\ Correspondence: Yunus Emre Campus, Education Faculty, Karamanoglu Mehmetbey University, Karaman, \\ Turkey. E-mail: selvakenanlar@hotmail.com
}

Received: December 1, 2019

Accepted: December 28, 2019 Online Published: January 6, 2020

doi:10.5539/jel.v9n1p156

URL: https://doi.org/10.5539/jel.v9n1p156

\begin{abstract}
Metacognition is important for learners of all ages. Therefore, this situation raises all important questions about how to develop metacognitive skills and habits in the classroom regardless of primary, secondary and high school. The aim of this study is to investigate the metacognitive awareness of primary and secondary school students according to the variables of gender, grade level and region. The model of this research, which was conducted to determine the metacognitive awareness levels of the students in primary and secondary school, is a survey model. Metacognitive Awareness Scale was administered to 399 students (195 girls, 204 boys) in third, fourth and fifth grade. The research shows that the metacognitive awareness scores of primary and secondary school students do not differentiate in gender. According to another result obtained in the research; metacognitive awareness scores of pirmary and secondary school students differentiate in locality. The students' metacognitive awareness is higher than that of the urban local. When the metacognitive awareness scores were examined according to the grade level, it was seen that the metacognitive awareness scores of the fifth grade students were higher than the other groups. However, there is no significant difference between the metacognitive awareness scores of the third and fourth grade students. Similar studies aiming to examine the development of metacognitive awareness of students are thought to be useful in planning the education process in this direction.
\end{abstract}

Keywords: metacognition, metacognitive awarenss, primary education, secondary education

\section{Introduction}

The concept of metacognition was developed by Brown and John Flavell about 40 years ago (Lin, 2001). Flavell defined metacognition as the knowledge of one's own cognitive processes (Crain, 1988). This process includes information about when one understands and does not understand, or how one uses existing knowledge to reach a goal, and develop a problem-solving strategy (Gourgey, 1998). Likewise, Costa (1984) defines metacognition as the ability to know what one does not know. Costa also states that some people are unaware of their own thinking processes. Such people cannot explain the steps or strategies they use during the problem-solving action. They cannot verbalise the visual images in their minds. They rarely evaluate the quality of their thinking skills (Ganz \& Ganz, 1990). Dirkes (1985) states that students who direct their own thinking generally do three things: associate their previous knowledge with new knowledge, identify thinking skills to solve a problem, and manage their time for learning purposes (Ganz \& Ganz, 1990). Dirkes defines this awareness of students as metacognition. This awareness affects the understanding of what is learned and how the new knowledge can be used to solve a problem, as well as development of effective learning, development of critical thinking and problem-solving skills. Metacognitive awareness allows thinking and thinking on learning processes and products, and its control over learning and self-assessment.

Metacognition is important for learners of all ages. Therefore, this raises all important questions about how to develop metacognitive skills and habits in the classroom. The first thing that needs to be done is to ensure that students have the opportunity to practice their metacognitive skills in the classroom and face situations that require metacognition. Students should be aware of the meaning and importance of metacognition, and capacity building should be a clear goal for both the teacher and the student. Indeed, this goal should have a permanent place in the education process (Martinez, 2006).

Metacognition is divided into sub-scales because it is a multi-faceted concept. The first classification was made 
by Flavel who introduced the concept of metacognition and he claimed that metacognition consisted of two sub-dimensions: metacognitive knowledge and metacognitive control. Brown (1987), another researcher working mainly on metacognition, categorised metacognition as cognitive knowledge and cognitive regulation. The literature shows that there are different classifications. However, over time, these classifications became clear and a consensus has been reached on two sub-scales: metacognitive knowledge and metacognitive control (Ozsoy, 2008).

Metacognitive knowledge is what one knows about how the cognitive processes take place (Flavell, 1979; Pintrich, 2002). In other words, it is the information that a person needs to perform a task successfully. For instance, the individual's awareness of one's cognitive abilities (ability to say that his/her memory is not good); the cognitive strategies one uses (to develop his/her own methods to easily remember phone numbers) and to know how to behave in which situation (knowing that categorized information can be remembered more easily) (Tanner \& Jones, 2000; cited in Ozsoy \& Gunindi, 2011).

Metacognitive knowledge is also divided into three sub-skills: declarative knowledge, procedural knowledge and state of knowledge. Declerative means having an idea about the information one possesses; procedural knowledge means knowledge of how to do a given task. In other words, a person knows what information he/she should use in the caes of a problem. State of knowledge is defined as knowing when and what information to use (Schraw \& Mosshman, 1995).

Many studies show that successful students have all three different types of knowledge. Many theorists argue that metacognitive knowledge has started to develop in children at an early age and continues to develop in adolescence (Schraw \& Mosshman, 1995).

Metacognitive control consists of basic mental processes and is described as the ability to use metacognitive information strategically to achieve cognitive goals (Ozsoy, 2008). In other words, it is a series of activities that help individuals control their own learning (Schraw, 1998). It consists of three sub-skills: planning, monitoring and evaluation (Jacobs \& Paris, 1987).

Planning involves selecting strategies that are appropriate to the problem and arranging solution resources that affect success, for example, to make predictions before reading, to determine the appropriate reading comprehension strategy (Schraw, 1998). Monitoring is one's potential and ability of using skills when dealing with a topic during the cognitive process.

Peeople regularly follow their own development during the learning process (Ozsoy \& Gunindi, 2011). Self-testing at certain intervals during the learning process, checking the learning level in the process are some examples of monitoring skills (Pressley \& Ghatala, 1990). The evaluation skill is aimed at whether the result appropriate to the learning objective reached at the end of the process (Schraw, 1998). In other words, it is about being aware of how efficient learning is.

High metacognitive awareness of students plays a significant role in quality education process. It is expected that identifying the metacognitive awareness of primary and secondary school students will be useful in the evaluation of current education. Therefore, the research aimed to compare the metacognitive awareness levels of primary and secondary school students according to the variables of gender, grade and locality of study. The study seeks to answer following research questions:

1) Do the metacognitive awareness levels of primary and secondary school students differ according to gender?

2) Do the metacognitive awareness levels of primary and secondary school students vary according to the locality variable?

3) Do metacognitive awareness levels of primary and secondary school students differ according to grade variable?

\section{Method}

The relational survey model as one of the quantitative research methods was used in the research. The relational survey model aims to determine the presence or degree of change between two and more variables (Cohen, Manion, \& Morrison, 2000). Relational survey can be done in two ways: correlation and comparison. Correlation-type relationships are sought in order to find out whether the variables change together if there is a change. Comparison type is a research design that has no trials but is close to it (Karasar, 2005).

\subsection{Sample Group}

The study group consists of primary school 3th and 4th grades and middle school 5th grade students receiving education in the 2018-2019 academic year. The study group was chosen by the purposeful criterion sampling 
method. In the case of the criterion sample, all conditions are studied within the criteria previously prepared by the researcher (Yıldırım \& Şimşek, 2006). Attributes related to participants are presented in Table 1 and Table 2:

Table 1. Information about the demographic characteristics

\begin{tabular}{lll}
\hline Demographic Characteristic & $\mathrm{f}$ & $\%$ \\
\hline Girls & 195 & 48.9 \\
Boys & 204 & 51.1 \\
Total & 399 & 100.0 \\
\hline
\end{tabular}

Table 2. Information about the participant types

\begin{tabular}{lll}
\hline Participant Types & $\mathrm{f}$ & $\%$ \\
\hline 3 th grade students & 114 & 28.6 \\
4 th grade students & 151 & 37.8 \\
5 th grade students & 134 & 33.6 \\
\hline Total & 399 & 100.0 \\
\hline
\end{tabular}

Table 3. Information about the locality

\begin{tabular}{lll}
\hline Locale & f & $\%$ \\
\hline Rural & 232 & 58.1 \\
Urban & 167 & 41.9 \\
\hline Total & 399 & 100.0 \\
\hline
\end{tabular}

\subsection{Collection of Data}

Jr MAI scale developed by Sperling et al. (2002) was used in this research. The scale aims to identify the children's metacognitive awarenss. The scale is based on Metacognitive Awareness Inventory (MAI) developed by Schraw and Dennison (1994) for adults and consists of two forms. The adaptation of the scale into Turkish was done by Karakalle and Sarac (2007) and it was named Metacognitive Awareness Scale for Children: Forms $\mathrm{A}$ and $\mathrm{B}$.

Form A has 3-point Likert style questions with the options of 'always, sometimes and never.' B form has 5-point Likert style question (never, randomly, sometimes, frequently, always). The lowest score for form A of the scale is 12 , the highest score is 36 , while the lowest score for form B is 18 and the highest is 90 (Karakalle \& Sarac, 2007). Since the study was conducted with third, fourth and fifth grade students, the form A was used.

\subsection{Data Analysis}

SPSS 18.0 was used to analyse the data. The t-test for independent groups was utilised to examine the scores of the students from Metacognitive Awareness Scale according according to the varibales of gender and region of study. One-way analysis of variance (ANOVA) was used to conduct the analysis of grade variable. Before the parametric tests, it was examined whether the study group showed normal distribution (skewness and kurtosis values). The Skewness values were found to be -.314 and kurtosis was calculated as -.321. Since the values are between -1 and +1 , there is a normal distribution. Levene test was applied to test homogeneity which is the other assumption of parametric tests. According to gender, region and grade variables, $\mathrm{p}$ value was higher than .05. Based on these findings, parametric tests were used for data analysis.

\section{Findings}

When the metacognitive sacel total scores of the 3rd, 4th and 5th grade students were examined, it was observed that they were in the general middle-to-high level $(\overline{\boldsymbol{x}}=26.67, \mathrm{~S}=4.84)$.

\subsection{Findings of Metacognitive Awareness Levels of Primary and Secondary School Students in Terms of Gender Variable}

Table 4 presents the metacognitive awareness of primary and secondary school students in terms of gender variable. 
Table 4. Results showing significance of difference between means of scores of metacognitive awareness of students based on gender

\begin{tabular}{llllll}
\hline Gender & $\mathrm{N}$ & $\overline{\boldsymbol{x}}$ & $\mathrm{Ss}$ & $\mathrm{T}$ & $\mathrm{p}$ \\
\hline Girls & 195 & 26.90 & 4.67 & .91 & $.36^{*}$ \\
Boys & 204 & 26.46 & 5.00 & & \\
\hline
\end{tabular}

When Table 4 is examined, it is seen that the mean scores of metacognitive awareness of female students are $(\overline{\boldsymbol{x}}=26.90)$, while the mean score of male students is $(\overline{\boldsymbol{x}}=26.46)$. When the difference between the mean scores of metacognitive awareness scores of the two groups was checked with $\mathrm{t}$ test $(\mathrm{t}=.91)$ it was concluded that there was no significance.

3.2 Findings of Metacognitive Awareness Levels of Primary and Secondary School Students in Terms of Locale Variable

Table 5 presents the metacognitive awareness of students according to the locale variable (rural vs urban)

Table 5. Results showing significance of difference between means of scores of metacognitive awareness of students based on locality

\begin{tabular}{llllll}
\hline Locale & $\mathrm{N}$ & $\overline{\boldsymbol{x}}$ & $\mathrm{Ss}$ & $\mathrm{T}$ & $\mathrm{p}$ \\
\hline Rural & 167 & 24.99 & 5.22 & -6.15 & $.00^{*}$ \\
Urban & 232 & 27.88 & 4.15 & & \\
\hline
\end{tabular}

Table 5 presents that mean scores of metacognitive awareness of the students. The mean scores of students in rural areas is $(\overline{\boldsymbol{x}}=24.99)$ while the average score of the students studying in urban areas is $(\overline{\boldsymbol{x}}=27.88)$. When the $\mathrm{t}$-test $(\mathrm{t}=-6.91)$ was used to check whether the difference between the metacognitive awareness scores of the two groups according to the region of study was significant, it was found to be significant at .05 level. In this case, the metacognitive awareness level of the students studying in urban areas is significantly higher than the students studying in rural areas.

3.3 Findings of Metacognitive Awareness Levels of Primary and Secondary School Students in Terms of Grade Level Variable

Table 6 presents the metacognitive awareness of the students according to the grade variable.

Table 6. Results showing significance of difference between means of scores of metacognitive awareness of students based on grade variable

\begin{tabular}{llll}
\hline Class Level & $\mathrm{N}$ & $\overline{\boldsymbol{x}}$ & $\mathrm{Ss}$ \\
\hline $5^{\text {th }}$ Grade & 134 & 28.15 & 3.92 \\
$4^{\text {th }}$ Grade & 151 & 26.29 & 5.49 \\
$3^{\text {th }}$ Grade & 114 & 25.43 & 4.49 \\
Total & 399 & 26.67 & 4.84 \\
\hline
\end{tabular}

As seen in Table 6, metacognitive awareness of 5th grade students is $(\overline{\boldsymbol{x}}=28.15)$; 4th grade is $(\overline{\boldsymbol{x}}=26.29)$ and 3rd grade is $(\overline{\boldsymbol{x}}=25.43)$.

Table 7. One-way ANOVA results of primary and secondary school students' metacognitive awareness scores in terms of grade variable

\begin{tabular}{cllllll}
\hline Dependent Variable & The source of the variance & Sum of Squares & S.D. & Mean of Squares & F & P \\
\hline & Within Groups & 489.925 & 2 & 244.962 & & \\
Grade & Among Groups & 8857.369 & 396 & 22.367 & 10.952 & $\mathbf{. 0 0}^{*}$ \\
& Total & 9347.293 & 398 & & & \\
\hline Note. $* \mathrm{p}<0,05$. & & & & &
\end{tabular}

According to Table 7, there was a significant difference in metacognitive awareness scores $(\mathrm{F}=10.952)$ of primary and secondary school students in terms of grade level variable. Tukey HSD test was performed to 
determine the source of the differentiation and the results are given in Table 8 below.

Table 8. Tukey HSD test results regarding metacognitive awareness scores of primary and secondary school students in terms of grade level variable

\begin{tabular}{|c|c|c|c|c|c|}
\hline & Grade & & Difference of Mean Scores & Standard Deviation & $\mathrm{p}$ \\
\hline \multirow[t]{3}{*}{ Metacognitive awareness } & $5^{\text {th }}$ Grade & $4^{\text {th }}$ Grade & $1.85(*)$ & .56 & $.003 *$ \\
\hline & & $3^{\text {th }}$ Grade & 2.71(*) & .54 & $.000 *$ \\
\hline & $4^{\text {th }}$ Grade & $3^{\text {th }}$ Grade & .85 & .61 & .413 \\
\hline
\end{tabular}

Note. $* \mathrm{p}<0.05$.

There was a significant difference at the level of 0.5 between the metacognitive awareness scores of the 5 th grade and the 4th grade students. Metacognitive awareness of 5th grade students is significantly higher than the metacognitive awareness of 4th grade students. There was also a significant difference $(0.5)$ between the metacognitive awareness socare of 5th and 3rd grade students. Metacognitive awareness of 5th grade students is significantly higher than the metacognitive awareness of 3 th grade students. There is no significant difference between the metacognitive awareness scores of the 4th grade students and the metacognitive awareness scores of the 3 th grade students.

\section{Discussion and Conclusion}

The aim of this study was to examine and compare the metacognitive awareness levels of primary and secondary school students in terms of gender, locality and grade variables. The participants of the research were 232 students studying in three primary and two secondary schools in Konya city center and 167 students studying in 2 primary and 2 secondary schools in Cumra and Akoren districts of the city center.

The data collection tool of the research was Jr. MAI Scale developed y Sperling, Howard, Miller and Murphy (2002) to determine the metacognitive awareness of children. The scale was adapted to Turkish by Karakalle and Sarac (2007) and re-named as Metacognitive Awareness Scale for Children: Forms A and B. There has been severel reasearch on metacognitive awareness in Turkey and majority of this research use Metacognitive Awareness Inventory (MAI) developed by Schraw and Dennison in 1994.

When literature is examined, various researches about metacognitive awareness have been done (Akin, 2006; Aktag, Semsek, \& Tuzcuoglu, 2017; Bagceci et al., 2011; Baykara, 2011; Demirsoz, 2010; Emrahoglu \& Ozturk, 2010; Kramarski, 2004; Gul et al., 2015; Gursimsek et al., 2009; Kiremitci, 2011; Pilten, 2008; Turan \& Demirel, 2010; Yavuz, 2009).

In this research, it was examined whether the metacognitive awareness levels and metacognitive awareness of the students showed significant differences according to various variables. Yavuz (2009), Demirsoz (2010) and Gul et al. (2015) by gender; Akin (2006), Emrahoglu and Ozturk (2010), Bagceci et al. (2011) according to the academic achievement of students; Ozsoy \& Gunindi (2011) stated that pre-school teachers' age, education level and high school type; Dilci and Kaya (2012) class teachers according to age, gender, marital status, seniority, graduation status and the school variable they graduated; Emrahoglu \& Ozturk (2010) and Turan \& Demirel (2010), according to the academic achievement of students; Kramarski (2004), Gursimsek et al. (2009), Pilten (2008), Kiremitci (2011) according to problem solving skills; Baykara (2011), on the other hand, investigated whether the metacognitive awareness of the students showed a significant difference according to their teacher competence perceptions.

There are very few metacognitive awareness studies conducted with primary school students (Gursimsek et al., 2009; Ozsoy \& Gunindi, 2011; Dilci \& Kaya, 2012; Baysal et al., 2013). Therefore, it is thought that this research will contribute to the literature as it is one of the few metacognitive awareness studies conducted with small age groups.

The results show that metacognitive awareness scores of primary and secondary school students do not differ significantly according to gender. This result echoes the findings of Kapucu \& Oksuz (2015). Kapucu and Oksuz study with 448 secondary school students; they concluded that their metacognitive awareness did not change between male and female students. In a similar study, Saracoglu \& Cengel (2013); gender factors concluded that metacognitive awareness was not predictive variable. Similar results have been obtained in many studies conducted in Turkey and abroad (Veloo et al., 2015; Rahman et al., 2010; Jaleel \& Premachandran, 2016).

The research also shows the metacognitive awareness scores of the students differ significantly according to the 
locality (rural vs urban) they are studying. Metacognitive awareness scores of the students studying in the urban areas were higher than those of the students studying in rural areas. This may be explained by the factors such as the students in urban areas are in a more active educational environment and encountering more stimuli. In a similar study (Jaleel \& Premachandran, 2016), contrary to the results obtained in this study, no significant difference was found according to locality. In Turkey, due to the lack of a similar study by locale variable, the results cannot be compared. However, a more in-depth review in another study would be useful to identify the sub-causes of this result.

When the metacognitive awareness scores of the students were examined according to the grade level, which is another sub-question of the research, it was seen that the metacognitive awareness scores of the fifth-grade students were higher than the third and fourth grade students. However, there was no significant difference between metacognitive awareness scores of third and fourth grade students. While the levels of metacognitive development are less active during the primary school period, the students' awareness about how much they will learn and how to effectively use what they have learned at the secondary school incrases. In the studies conducted on metacognitive awareness and grade level, results were obtained in parallel with the results obtained in this study (Ozturk \& Kurtulus, 2017; Ozdemir \& Arik, 2018).

If one aim of schooling is to prepare children to be lifelong learners, then it is important to help students become aware of themselves as learners and to take control of their own activities. it is possible for students to know themselves and to take control of their learning activities by gaining metacognitive awareness. The students who gain metacognitive awareness are also conscious individuals who know what they learn and why and how to use the information they learn. In this context the investigators got an interest in the area metacognitive awareness.

Therefore, the research aimed to compare the metacognitive awareness levels of primary and secondary school students according to the variables of gender, grade and locality of study. Based on the results obtained, the following suggestions can be made;

$>$ Education and training process; both should be designed to enable students to think about themselves and to develop an awareness of themselves.

$>$ Teachers should know that students' individual metacognitive awareness differs and regulate the classroom environment in this direction.

$>$ In addition, innovative teaching methods and activities should be applied to identify and develop students' metacognitive awareness.

$>$ The performance and academic achievements of the students who developed their metacognitive abilities will improve in the same direction.

\section{References}

Akin, A. (2006). Başarı amaç oryantasyonları ile biliş̧ötesi farkındalık, ebeveyn tutumları ve akademik başarı arasindaki ilişkiler. Unpublished Master's Thesis, Sakarya University, Social Sciences Institute, Sakarya, Turkey.

Aktag, I., Semsek, O., \& Tuzcuoglu, S. (2017). Determination Metacognitive Awareness of Physical Education Teachers. Journal of Education and Training Studies, 5(9), 63-69. https://doi.org/10.11114/jets.v5i9.2511

Bagceci, B. et al. (2011). İlköğretim öğrencilerinin üstbilişsel farkındalık düzeyleri ile akademik başarısı arasındaki ilişkinin incelenmesi. Mustafa Kemal Üniversitesi Sosyal Bilimler Enstitüsü Dergisi, 8(16), 551566.

Baykara, K. (2011). Öğretmen adaylarının bilişötesi öğrenme stratejileri ile öğretmen yeterlik algıları üzerine bir çalışma. Hacettepe Üniversitesi Ĕ̈itim Fakültesi Dergisi, 40(1), 80-92.

Baysal, Z. N. et al. (2013). Sınıf Öğretmeni Adaylarının Üstbilişsel Farkındalıklarının Farklı Değişkenler Açısından İncelenmesi. M.Ü. Atatürk Eğitim Fakültesi Eğitim Bilimleri Dergisi, 37(37), 68-81.

Cohen, L., Manion, L., \& Morrison, K. (2000). Research methods in education. London: Routledge Falmer. https://doi.org/10.4324/9780203224342_chapter_1

Crain, S. K. (1988). Metacognition and the Teaching of Reading. Journal of Reading, 31(7), 682-685.

Demirsoz, E. S. (2010). Yaratıcı dramanın ögretmen adaylarının demokratik tutumları, bilişüstü farkındalıkları ve duygusal zekâ yeterliliklerine etkisi. Unpublished Master's Thesis, Dokuz Eylül University, Education Science Institute, İzmir, Turkey.

Dilci, T., \& Kaya, S. (2012). 4. ve 5. Sınıflarda Görev Yapan Sınıf Öğretmenlerinin Üstbilişsel Farkındalık 
Düzeylerinin Çeşitli Değişkenler Açısından İncelenmesi. Süleyman Demirel Üniversitesi Fen-Edebiyat Fakültesi Sosyal Bilimler Dergisi, 12(27), 247-267.

Emrahoglu, N., \& Ozturk, A. (2010). Fen bilgisi öğretmen adaylarının akademik başarılarına bilişsel farkındalığın etkisi: Bir nedensel karşılaştırma araştırması. Ç.Ü. Sosyal Bilimler Enstitüsü Dergisi, 19(2), $18-30$.

Flavell, J. H. (1979). Metacognitive aspects of problem solving. In L. B. Resnick (Ed.), The Nature of Iintelligence (pp. 231-235). Hillsdale, NJ: Lawrence Erlbaum.

Ganz, M. N., \& Ganz, B. C. (1990). Linking Metacognition to Classroom Success. The High School Journal, 73(3), 180-185.

Gourgey, A. F. (1998). Metacognition in Basic Skills Instruction. Instructional Science, 26(1/2), 81-96. https://doi.org/10.1023/A:1003092414893

Gul, S. et al. (2015). Biyoloji öğretmeni adaylarının üstbiliş farkındalıklarının farklı değişkenler açısından incelenmesi. Hasan Ali Yücel Eğitim Fakültesi Dergisi, 12(23), 119-130.

Gursimsek, I. et al. (2009). Okul Öncesi Öğretmenliği Öğrencilerinin Bilişüstü Farkındalık Düzeyleri ile Problem Çözme Becerilerinin İncelenmesi. The First International Congress of Educational Research, 1-3 Mayıs 2009 Çanakkale, Turkey.

Jacobs, J. E., \& Paris, S. G. (1987). Childrens' Metacognition About Reading: Issues in Definition, Measurement and Instruction. Educational Psychologist, 22(3-4), 255-278. https://doi.org/10.1207/s15326985ep2203\&4_4

Jaleel, S., \& Premachandran, P. (2016). A Study on the Metacognitive Awareness of Secondary School Students. Universal Journal of Educational Research, 4(1), 165-172.

Kapucu, M. S., \& Oksuz, R. (2015). Ortaokul Öğrencilerinin Üstbilişsel Farkındalıklarının İncelenmesi. Eğitim ve Insani Bilimler Dergisi: Teori ve Uygulama, 6(12), 5-28.

Karakelle, S., \& Sarac, S. (2007). Çocuklar için Üst Bilişsel Farkındalık Ölçeği (ÜBFÖ-Ç) A ve B formları: Geçerlik ve güvenirlik çalışması. Türk Psikoloji Yazıları, 10(20), 87-103.

Karasar, N. (2005). Bilimsel araştırma ve yöntemi (15th ed.). Ankara: Nobel Yayın Dağıtım.

Kiremitci, O. (2011). Beden eğitimi öğretmen adaylarının üstbilişsel farkındalık ve problem çözme becerileri arasındaki ilişkinin incelenmesi. Selçuk Üniversitesi Beden Ĕ̆itimi ve Spor Bilim Dergisi, 13(1), 92-99.

Kramarski, B. (2004). Making sense of graphs: Does metacognitive instruction make a difference on students' mathematical conceptions and alternative conceptions. Learning and Instruction, 14, 593-619. https://doi.org/10.1016/j.learninstruc.2004.09.003

Lin, X. (2001). Designing Metacognitive Activities. Educational Technology Research and Development, 49(2), 23-40. https://doi.org/10.1007/BF02504926

Martinez, M. E. (2006). What Is Metacognition? The Phi Delta Kappan, 87(9), 696-699. https://doi.org/10.1177/003172170608700916

Ozdemir, E. B., \& Arik, S. (2018). Çocukların Üstbilişsel Farkındalıkları ile Sürdürülebilir Kalkınmaya Yönelik Tutumlarının İncelenmesi. Estüdam Eğitim Dergisi, 3(1).

Ozsoy, G. (2008). Üstbiliş. Türk Ĕgitim Bilimleri Dergisi, 6(4), 713-740.

Ozsoy, G., \& Gunindi, Y. (2011). Okulöncesi Öğretmen Adaylarının Üstbilişsel Farkındalık Düzeyleri. İlkögretim Online, 10(2), 430-440.

Ozturk, B., \& Kurtulus, A. (2017). Ortaokul Öğrencilerinin Üstbilişsel Farkındalık Düzeyi İle Matematik Öz Yeterlik Algısının Matematik Başarısına Etkisi. Dicle Üniversitesi, Ziya Gökalp Eğitim Fakültesi Dergisi, 31, 762-778. https://doi.org/10.14582/DUZGEF.1840

Pilten, P. (2008). Üstbilişs stratejileri ögretiminin ilköğretim beşinci sinıf öğrencilerinin matematiksel muhakeme becerilerine etkisi. Unpublished Master's Thesis, Gazi Üniversitesi, Eğitim Bilimleri Enstitüsü, Ankara.

Pintrich, P. R. (2002). The Role of Metacognitive Knowledge in Learning, Teaching, and Assessing. Theory Into Practice, 41(4), 219-225.

Pressley, M., \& Ghatala, E. S. (1990). Self-regulatedlearning: Monitoring Learning from Text. Educational Psychologist, 25(1), 19-33. https://doi.org/10.1207/s15326985ep2501_3 
Rahman, F. et al. (2010). Impact of Metacognitive Awareness on Performance of Students in Chemistry. Contemporary Issues in Education Research, 3(10). https://doi.org/10.19030/cier.v3i10.237

Saracoglu, A. S., \& Cengel, M. (2013). Cinsiyet, Yaş ve Düşünme İhtiyacı Düzeyinin Bilişötesi Farkındalığı Yordayıc1lı̆̆ı. İnönü Üniversitesi Eğitim Fakültesi Dergisi, 14(1), 1-13.

Schraw, G. (1998). Promoting General Metacognitive Awareness. Instructional Science, 26(1-2), 113-125. https://doi.org/10.1023/A:1003044231033

Schraw, G., \& Moshman, D. (1995). Metacognitive Theories. Educational Psychology Review, 7(4), 351-371. https://doi.org/10.1007/BF02212307

Schraw, G., \& Sperling-Dennison, R. (1994). Assessing metacognitive awareness. Contemporary Educational Psychology, 19, 460-470.

Sperling, R. A. et al. (2002). Measures of children's knowledge and regulation of cognition. Contemporary Educational Psychology, 27(1), 51-79.

Tanner, H., \& Jones, S. (2000). Becoming a successful teacher of mathematics. London, UK: RoutledgeFalmer.

Turan, S., \& Demirel, Ö. (2010). In what level and how medical students use metacognition? A case from Hacettepe University. Procedia - Social and Behavioral Sciences, 2(2), 948-952. https://doi.org/10.1016/j.sbspro.2010.03.132

Veloo, A. et al. (2015). The Role of Gender in the Use of Metacognitive Awareness Reading Strategies among Biology Students. Asian Social Science, 11(1), 67. https://doi.org/10.5539/ass.v11n1p67

Yavuz, D. (2009). Öğretmen adaylarının özyeterlilik algıları ve üstbilişsel farkındalıklarının çeşitli değişkenler açısından incelenmesi. Unpublished Master Thesis, Karaelmas Üniversitesi, Sosyal Bilimler Enstitüsü, Zonguldak, Turkey.

Yildirim, A., \& Simsek, H. (2006). Sosyal bilimlerde nitel araştırma yöntemleri (6th ed.). Ankara: Seçkin Yayıncilik.

\section{Copyrights}

Copyright for this article is retained by the author, with first publication rights granted to the journal.

This is an open-access article distributed under the terms and conditions of the Creative Commons Attribution license (http://creativecommons.org/licenses/by/4.0/). 